Halaman 11-22

\title{
Peningkatan Kemampuan Berpikir Kritis dan Hasil Belajar Biologi Siswa Kelas VII-A Melalui Penerapan Model Guided Inquiry dengan Bantuan Social Network Facebook di SMPN 1 Kartasura
}

\section{The Improvement of The Students' Critical Thinking Ability and Achievement in Biology Of VII A Class Through Implementation of Guided Inquiry Model Assisted by the Use of Social Network Facebook in SMPN 1 Kartasura}

\author{
Fildza Hilfi Fanani ${ }^{a}$, Riezky Maya $\mathbf{P}^{\mathrm{b}}$, Suciati ${ }^{\mathrm{c}}$ \\ a Pendidikan Biologi FKIP UNS, Email: hilfi63fanani@gmail.com \\ ${ }^{\mathrm{b}}$ Pendidikan Biologi FKIP UNS, Email: riezkymp@gmail.com \\ ${ }^{c}$ Pendidikan Biologi FKIP UNS, Email: suciati.sudarisman@yahoo.com
}

Diterima 21 Agustus 2013, disetujui 17 Januari 2014

\begin{abstract}
This study is aimed at improving the students' critical thinking ability and achievement in Biology of VII A class of SMPN 1 Kartasura through the implementation of guided inquiry model assisted by the use of facebook. This research is a classroom action research involving several cycles in which each cycle includes four stages those are planning, action, observation, and reflection. The subject of this research is the students of VII A class at SMPN 1 Kartasura in academic year of 2012/2013. The data are obtained through the test (essay and multiple-choice) and non-test (observation, interviews and questionnaires). The data are analyzed through descriptive analytical techniques and validated through triangulation techniques. Critical thinking ability consists of six aspects those are interpretation, analysis, evaluation, inference, explanation, and self-regulation. The average improvement percentage of critical thinking ability test in Pre-cycle, Cycle I, Cycle II, and Cycle III sequently are $(41,36 \% ; 52,66 \% ; 65,32 \% ; 77,26 \%)$. Students' achievement is viewed from the increase of student learning completeness consisting of cognitive, psychomotor, and affective. The result of percentage attainment average from cognitive aspects in Pre-cycle, Cycle I, Cycle II, and Cycle III sequently are (36,11\%; $47,22 \% ; 72,22 \% ; 100 \%)$. Psychomotor students' achievement consists of three aspects, those are stringing experimental tool, observing the object changes that occur in the experiment, and communicating the results of experiments and worksheets in the presentation. The result of percentage attainment average from psychomotor aspects in Cycle I, Cycle II, and Cycle III sequently are (64,12\%; 81,25\%; 90,66\%). Affective students' achievement includes three aspect which are being meticulous in observing object from results of the experiment, being discipline in collecting worksheets, and being cooperative in a group discussion. The result of percentage attainment average from affective aspects in Cycle I, Cycle II, and Cycle III sequently are $(61,81 \% ; 77,31 \% ; 91,92 \%)$. Based on the results of the research it can be concluded that the implementation of guided inquiry model assisted by the use of facebook can improve the students' critical thinking ability and achievement in Biology of VII A class of SMPN 1 Kartasura.
\end{abstract}

Key Words: Guided Inquiry, Facebook, Biology Critical Thinking Ability, Students' Achievement in Biology

\section{Pendahuluan}

Era globalisasi dan kemajuan

Ilmu Pengetahuan dan Teknologi
(IPTEK) mendorong persaingan antar negara sehingga membutuhkan sumber daya manusia yang memiliki daya saing tinggi dan Sumber Daya Manusia (SDM) 
yang menuntut untuk berpikir tingkat tinggi di antaranya kritis, kreatif, dan inovatif. Menyikapi persaingan global tersebut dalam Standar Isi Permendiknas dinyatakan bahwa peningkatan mutu pendidikan diarahkan untuk meningkatkan kualitas manusia Indonesia seutuhnya melalui olahhati, olahpikir, olahrasa dan olahraga agar memiliki daya saing dalam menghadapi tantangan global (BSNP, 2006). Kebutuhan SDM suatu negara yang menuntut untuk bisa berpikir tinggi sangat berhubungan erat dengan pendidikan. Pendidikan sebagai pencetak generasi penerus bangsa yang mampu bersaing di era globalisasi seharusnya memberdayakan siswa untuk membiasakan berpikir tingkat tinggi untuk memecahkan masalah sejak belajar di sekolah.

Pembelajaran sains sebagai salah satu pendorong kemajuan teknologi informasi dan komunikasi pada era globalisasi harus diajarkan sesuai dengan hakikat pembelajaran sains yang mencakup ranah kognitif (minds on), afektif (hearts on) dan psikomotor (hands on) (Rustaman, 2011). Biologi

termasuk ke dalam sains merupakan ilmu yang harus berkembang dengan berbantu teknologi. Hal ini melihat bahwa Biologi merupakan pembelajaran yang abstrak sehingga memerlukan alat bantu untuk pemahaman konsep agar hasil belajar baik. Biologi termasuk ke dalam sains tidak hanya belajar fakta, konsep, prinsip, hukum, tetapi juga belajar tentang bagaimana memperoleh informasi, menerapkan teknologi dalam sains, bekerja secara ilmiah, dan kemampuan berpikir (Wenno, 2008). Pembelajaran Biologi mencakup semua aspek yaitu kognitif (minds on), afektif (hearts on) dan psikomotor (hands on) sehingga siswa perlu dilibatkan aktif dalam pembelajaran Biologi agar belajar berhasil dengan baik.

Berpikir kritis sangat diperlukan dalam Biologi untuk membangun konsep secara mandiri dan menyikapi beragam fenomena Biologi yang terjadi di alam dan sekitar. Hal ini juga tercantum dalam permendiknas No.22 tahun 2006 bahwa Biologi yang merupakan kelompok mata pelajaran ilmu pengetahuan dan teknologi membudayakan siswa untuk berpikir ilmiah secara kritis, kreatif, dan mandiri (BSNP, 2006). Siswa yang memiliki pemikiran kritis yang tinggi dapat memahami konsep Biologi yang akan berdampak pada hasil belajar yang optimal sehingga mampu bersaing dengan bangsa lain di era globalisasi ini.

Hasil observasi terhadap proses pembelajaran Biologi kelas VII A SMPN 1 Kartasura tahun pelajaran 2012/2013 menunjukkan bahwa siswa menggunakan 
sumber belajar yang terbatas berupa buku paket, siswa kurang memperhatikan saat pembelajaran, hanya sedikit siswa yang bertanya kepada guru mengenai materi yang diajarkan, siswa menjawab pertanyaan dari guru sebesar 47,05\%. Observasi kedua menunjukkan bahwa siswa kurang menyatakan arti suatu informasi atau gambar, menganalisa permasalahan, menjelaskan pernyataan berdasarkan bukti, menilai pernyataan, membuat kesimpulan beralasan, dan mengevaluasi konsep yang diterima selama pembelajaran. Hal tersebut mengindikasikan bahwa kemampuan berpikir kritis siswa kurang optimal.

Pengamatan ini dikuatkan kembali dengan hasil ulangan harian dan tes Prasiklus kemampuan berpikir kritis. Berdasarkan hasil nilai ulangan harian dapat diketahui bahwa $36,11 \%$ siswa telah memenuhi KKM (Kriteria Ketuntasan Minimal) yang telah ditetapkan yaitu 75 serta $63,89 \%$ untuk siswa yang belum mencapai KKM. Analisa hasil ulangan harian diperoleh bahwa siswa kurang mampu untuk menjawab soal yang berkaitan dengan menganalisis, mengevaluasi, dan mencipta. Hal ini mengindikasikan siswa kurang mampu untuk menjawab soal berpikir tingkat tinggi. Berdasarkan hasil tes Prasiklus diketahui bahwa kemampuan berpikir kritis siswa masih rendah. Jika keadaan tersebut dibiarkan akan berdampak pada rendahnya kemampuan berpikir tingkat tinggi siswa khususnya berpikir kritis sehingga dapat mempengaruhi hasil belajar siswa menjadi kurang maksimal.

Berdasarkan wawancara di kelas VII A didapatkan hampir seluruh siswa mempunyai akun facebook dan beberapa siswa menggunakan untuk berkomunikasi serta sering melalaikan pembelajaran. Penggunaan teknologi seharusnya bukan menghambat pembelajaran tetapi bisa dimanfaatkan untuk mendukung proses pembelajaran.

Berdasarkan uraian di atas terdapat kesenjangan antara pembelajaran di kelas VII A SMPN 1 Kartasura dengan kondisi ideal pembelajaran menurut BNSP, serta tuntutan kemajuan zaman dan teknologi di era globalisasi. Hal ini perlu adanya perbaikan pembelajaran yang melibatkan siswa secara aktif mulai dari berpikir, berproses melakukan, dan menghasilkan suatu gagasan yang dibangun oleh siswa sendiri sehingga memberikan hasil belajar yang baik.

\section{Guided inquiry (inkuiri} terbimbing) adalah kegiatan penemuan dimana masalah dikemukakan guru kemudian siswa bekerja untuk menemukan jawaban terhadap masalah tersebut di bawah bimbingan guru secara 
intensif (Amri, 2010). Sintaks guided inquiry meliputi merumuskan masalah, mengajukan hipotesis, mengumpulkan data, menguji hipotesis, dan membuat kesimpulan yang menuntut siswa untuk menemukan konsep sendiri (Sanjaya, 2008).

Keunggulan dari guided inquiry adalah rangkaian kegiatan belajar melibatkan secara maksimal seluruh kemampuan siswa untuk mencari dan menyelidiki secara sistematis, kritis, logis, analitis (Gulo dalam Trianto, 2010). Menurut Andriani (2011) di dalam penelitiannya menjelaskan bahwa penerapan model pembelajaran guided inqury dapat meningkatkan antusias siswa dalam pelaksanaan kegiatan pembelajaran dan siswa menjadi fokus dalam pelaksanaan pembelajaran. Siswa menunjukkan aktivitas lisan dan berfikir di mana siswa mampu menjawab pertanyaan dan berdiskusi dalam kelas.

Guided inquiry jika diterapkan pada siswa akan lebih menarik jika menggunakan media. Media pembelajaran yang sangat banyak ini disesuaikan dengan kebutuhan siswa. Berkaitan dengan hampir semua siswa yang memiliki akun facebook dan sering menggunakannya , maka facebook menjadi alternatif pilihan untuk membantu model guided inquiry. Facebook sebagai social network mempunyai fitur - fitur untuk berinteraksi di antara sesama pengguna yaitu wall/dinding, inbox, chatting, dan lain - lain. Fitur tersebut juga dilengkapi dengan aplikasi beberapa aplikasi yaitu: photo, video, notes/catatan, event, quiz, group, link atau tautan (Kurniali, 2009).

Facebook mudah diakses mulai dari pendaftaran akun, fitur, aplikasi, dan tidak hanya bisa diakses lewat computer namun juga bisa lewat handphone. Melalui fitur tersebut materi dapat diunggah untuk didiskusikan. Adanya kombinasi antara guided inquiry dan $f a-$ cebook, siswa akan lebih tertarik mengikuti pembelajaran serta memanfaatkan arus perkembangan IPTEK sebagai pendukung proses pembelajaran. Kombinasi antara guided inquiry dan facebook diharapkan dapat meningkatkan kemampuan berpikir kritis siswa dan hasil belajar Biologi yang meliputi aspek kognitif, psikomotor dan afektif.

\section{Metode Penelitian}

Penelitian ini dilaksanakan pada semester genap Tahun Pelajaran 2012/2013 di kelas VII A SMPN 1 Kartasura, Sukoharjo Tahun Pelajaran 2012/2013 yang beralamat di Jl. Adi Sumarmo 37 Kartasura, Sukoharjo. Secara garis besar pelaksanaannya dibagi menjadi tiga tahap, yaitu: tahap 
persiapan, penelitian, dan penyelesaian. Penelitian Tindakan Kelas ini dilakukan dalam tiga siklus pada tanggal 1 Mei 2013 sampai 15 Mei 2013 dengan subjek penelitian yaitu siswa kelas VII A SMPN 1 Kartasura, Sukoharjo Tahun Pelajaran 2012/2013, yang berjumlah 36 siswa.

Sebelum dilaksanakan penelitian dilakukan tes awal sebagai dasar kemampuan berpikir kritis siswa dan melihat nilai ulangan harian siswa sebagai hasil belajar kognitif. Setelah dilakukan tindakan prasiklus maka diadakan tes pada setiap akhir siklus yang mengukur kemampuan berpikir kritis dan hasil belajar siswa terhadap materi yang diajarkan.

Pengumpulan data menggunakan teknik tes dan no tes. Teknik tes dengan soal uraian dan pilihan ganda. Teknik non tes dengan pengamatan/observasi, wawancara dan angket yang dilakukan saat proses pembelajaran dan setelah akhir siklus. Teknik yang digunakan untuk memeriksa validitas data yang digunakan dalam penelitian ini adalah triangulasi. Triangulasi adalah teknik pengumpulan data yang bersifat menggabungkan dari berbagai teknik pengumpulan data dan sumber data yang telah ada.

\section{Langkah-langkah operasional} penelitian pada tiap siklus ada empat, yaitu 1) perencanaan: berdasarkan hasil identifikasi masalah dari kegiatan observasi yang telah dilakukan sebelumnya, alternatif pemecahan masalah yang diajukan adalah dengan penerapan model guided inquiry berbantu facebook untuk meningkatkan kemampuan berpikir kritis dan hasil belajar siswa pada materi pencemaran lingkungan. Pada tahap ini dilakukan penyusunan skenario pembelajaran penyusunan silabus dan rencana pengajaran. Instrumen yang digunakan dalam penelitian juga disiapkan seperti tes hasil belajar kognitif, tes kemampuan berpikir kritis, LKS, lembar observasi, angket serta pedoman wawancara; 2) pelaksanaan: tindakan yang telah direncanakan diimplementasikan dalam bentuk penerapan model guided inquiry berbantu facebook Pelaksanaan tindakan diwujudkan dalam Rencana Pelaksanaan Pembelajaran (RPP); 3) Observasi: observasi dilakukan selama berlangsungnya proses pembelajaran. Observasi berupa kegiatan pemantauan, pencatatan serta pendokumentasian segala kegiatan selama pembelajaran. Observasi juga dilakukan pada keterlaksanaan pembelajaran model guided inquiry berbantu facebook; dan 4) refleksi: pada tahap ini dilakukan analisis proses dan dampak dari pelaksanaan tindakan. Hasil analisis pada tahap refleksi berupa kelebihan, kelemahan 
ataupun hambatan dalam pelaksanaan tindakan dasar perencanaan kegiatan pada siklus sebelumnya.

Indikator kinerja dalam penelitian ini meliputi enam aspek kemampuan berpikir kritis dan hasil belajar kognitif, psikomotor, dan afektif. Target pencapaian pada penelitian dengan model pembelajaran guided inquiry berbantu facebook sebesar $\geq 20 \%$ untuk tiap aspek pada kemampuan berpikir kritis dan minimal nilai 75 (KKM) untuk hasil belajar kognitif, psikomotor, dan afektif.

\section{Hasil dan Pembahasan}

Perbandingan pencapaian persentase kemampuan berpikir kritis kelas VII A SMPN 1 Surakarta Prasiklus, Siklus I, Siklus II, dan Siklus III disajikan pada Gambar 1.

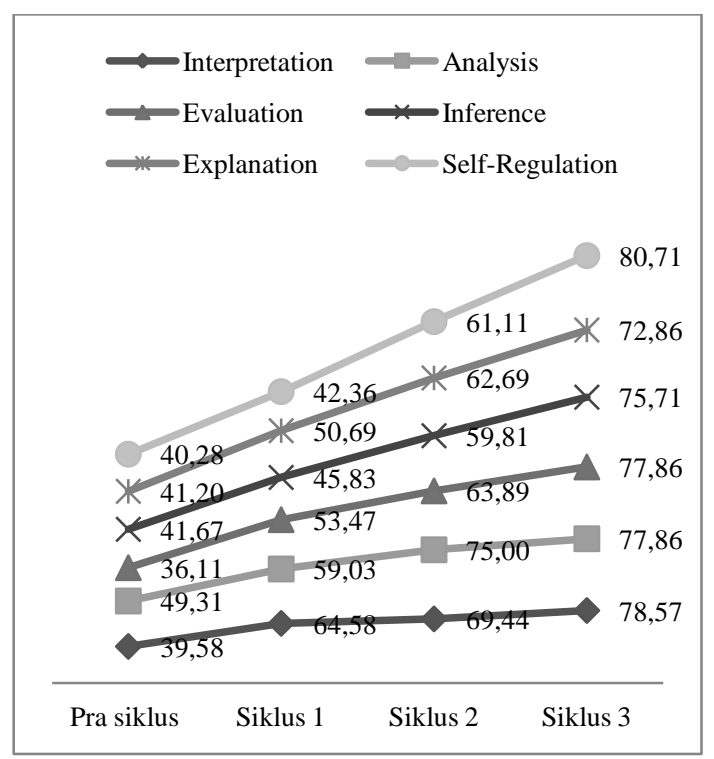

Gambar 1. Kurva Peningkatan Persentase Tes Kemampuan Berpikir Kritis Siswa Per Aspek pada Prasiklus, Siklus I, Siklus II dan Siklus III
Berdasarkan hasil penelitian didapatkan bahwa aspek interpretation meningkat dari Prasiklus sebesar 39,58\% menjadi $64,68 \%$ pada Siklus I, 69,44\% pada Siklus II, dan $78,57 \%$ pada Siklus III. Peningkatan pada aspek ini karena penggunaan model guided inquiry berbantu facebook dengan penemuan melalui sintak merumuskan masalah, membuat hipotesis, merancang percobaan, melakukan percobaan, menganalisis data, dan membuat kesimpulan. Siswa terbantu dalam menyatakan arti suatu konsep berupa wacana atau gambar pada materi pencemaran karena siswa melakukan sendiri penemuan di dalam proses belajar.

Aspek analysis meningkat dari Prasiklus sebesar 49,31\% menjadi 59,03 $\%$ pada Siklus I, 75,00\% pada Siklus II, dan $77,86 \%$ pada Siklus III. Model guided inquiry membiasakan siswa untuk menganalisis hasil percobaan melalui identifikasi dari jawaban pertanyaan pada LKS. Analisa ini mempermudah siswa untuk menemukan konsep pembelajaran pada materi pencemaran lingkungan.

Aspek evaluation juga meningkat dari Prasiklus sebesar 36,11\% menjadi $53,47 \%$ pada Siklus I, $63,89 \%$ pada Siklus II, dan $77,86 \%$ pada Siklus III. Aspek evaluation mengalami 
peningkatan terbesar dibandingkan dengan kelima aspek berpikir kritis yang lain. Keseluruhan sintak pada guided inquiry memberdayakan siswa untuk menemukan sendiri konsep belajar. Siswa terbantu untuk menilai konsep yang diterima pada pembelajaran dengan materi pencemaran lingkungan.

Aspek inference meningkat dari Prasiklus sebesar 41,67\% menjadi 45,83 $\%$ pada Siklus I, 59,81\% pada Siklus II, dan $75,71 \%$ pada Siklus III. Peningkatan ini terjadi karena pada sintak guided inquiry terdapat pembuatan kesimpulan yang berasal dari penemuan yang dilakukan sendiri oleh siswa. Hal tersebut membiasakan siswa untuk berpikir menyimpulkan konsep yang didapat dari pembelajaran khususnya di sini pada materi pencemaran lingkungan.

Aspek kelima yaitu explanation meningkat dari Prasiklus sebesar 41,20\% menjadi 50,69\% pada Siklus I, 62,69\% pada Siklus II, dan $75,86 \%$ pada Siklus III. Peningkatan ini terjadi karena siswa lebih mendalami pembelajaran dengan penemuan yang diterapkan pada Siklus I, Siklus II, dan Siklus III. Guru membimbing siswa melaksanakan percobaan yang diawali dengan wacana yang diambil dari fenomena pencemaran lingkungan. Keseluruhan sintak guided inquiry memberdayakan siswa untuk menjelaskan dengan bukti yang benar karena siswa membangun sendiri konsep belajar melalui penemuan.

Aspek berpikir kritis terakhir yaitu self-regulation meningkat dari Prasiklus sebesar 40,28\% menjadi $42,36 \%$ pada Siklus I, $61,11 \%$ pada Siklus II, dan $80,71 \%$ pada Siklus III. Sintak guided inquiry melalui percobaan ini mengaplikasikan konsep pada materi pencemaran lingkungan. Hal ini membiasakan siswa untuk memonitor konsep yang diterima dari pembelajaran melalui aplikasi tersebut.

Perbandingan pencapaian persentase hasil belajar kognitif kelas VII A SMPN 1 Surakarta Prasiklus, Siklus I, Siklus II, dan Siklus III disajikan pada Gambar 2.

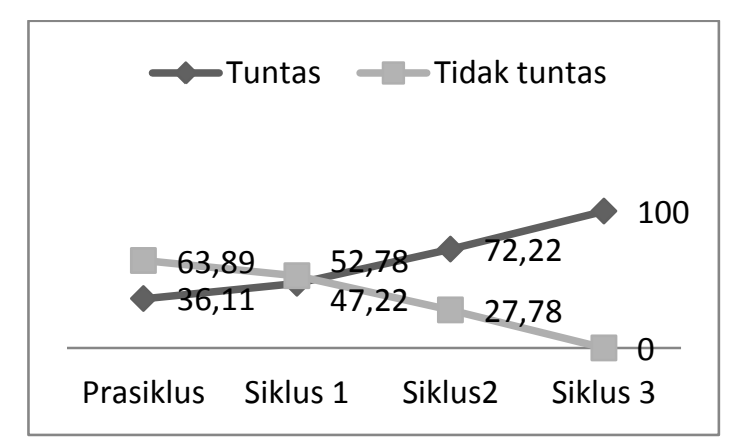

Gambar 2. Kurva Perbandingan Persentase Hasil Belajar Kognitif Prasiklus, Siklus I, Siklus II, dan Siklus III.

Hasil nilai ulangan harian sebagai hasil belajar kognitif pada Prasiklus dengan materi organisasi kehidupan menunjukkan siswa yang mencapai KKM (Kriteria Ketuntasan Minimal) yaitu 75 sebesar $36,11 \%$ dan siswa yang 
berada di bawah KKM sebesar 63,89\%. Evaluasi sebagai hasil belajar kognitif pada Siklus I, Siklus II, dan Siklus III menggunakan materi pencemaran lingkungan. Hasil evaluasi pada Siklus I siswa yang mencapai KKM sebesar $47,22 \%$ dan siswa yang berada di bawah KKM sebesar 52,78\%. Siklus II didapatkan siswa yang memenuhi KKM sebesar $72,22 \%$ dan siswa yang tidak memenuhi KKM sebesar 27,78\%. Terakhir pada Siklus III didapatkan bahwa $100 \%$ siswa berada di atas KKM. Peningkatan pada hasil belajar kognitif ini karena penggunaan model guided inquiry berbantu facebook melalui sintak merumuskan masalah, membuat hipotesis, merancang percobaan, melakukan percobaan, menganalisis data, dan membuat kesimpulan. Siswa melakukan sendiri kegiatan belajar melalui penemuan dengan dibimbing guru sehingga konsep materi pencemaran lingkungan lebih dimengerti siswa.

Perbandingan pencapaian persentase hasil belajar psikomotor kelas VII A SMPN 1 Surakarta dari Prasiklus, Siklus I, Siklus II, dan Siklus III disajikan pada Gambar 3.

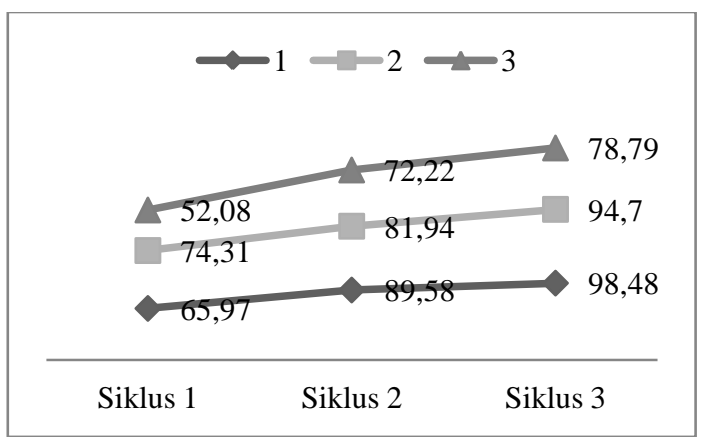

1. Merangkai alat percobaan (pengaruh limbah rumah tangga terhadap air, pengaruh aktivitas rumah tangga terhadap udara, dan pengaruh pupuk anorganik terhadap tanah).

2. Mengamati perubahan objek yang terjadi pada percobaan.

3. Mengkomunikasikan hasil percobaan dan LKS dalam bentuk presentasi.

Gambar 3. Kurva perbandingan Persentase Hasil Belajar Psikomotor Prasiklus, Siklus I, Siklus II, dan Siklus III.

Hasil belajar psikomotor meliputi tiga aspek yaitu merangkai alat percobaan, mengamati perubahan objek yang terjadi pada percobaan, dan mengkomunikasikan hasil percobaan dan LKS dalam bentuk presentasi. Aspek merangkai alat percobaan meningkat dari Siklus I sebesar 65,97\% menjadi 89,58\% pada Siklus II, dan 98,48\% pada Siklus III. Aspek mengamati perubahan objek yang terjadi pada percobaan juga meningkat dari Siklus I sebesar 74,31\%, menjadi $81,94 \%$ pada Siklus II, dan 94,70\% pada Siklus III. Aspek mengkomunikasikan hasil percobaan dan LKS dalam bentuk presentasi juga meningkat dari Siklus I sebesar 52,08\% 
menjadi $72,22 \%$ pada Siklus II, dan $78,79 \%$ pada Siklus III.

Perbandingan pencapaian persentase hasil belajar afektif kelas VII A SMPN 1 Surakarta dari Prasiklus, Siklus I, Siklus II, dan Siklus III disajikan pada Gambar 4.

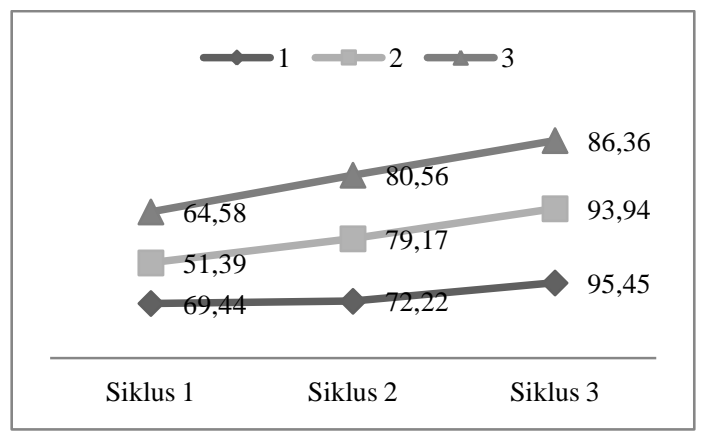

1. Teliti dalam mengamati objek hasil percobaan.

2. Disiplin dalam mengumpulkan LKS.

3. Bekerja sama dalam diskusi kelompok.

Gambar 4. Kurva Perbandingan Persentase Hasil Belajar Afektif Prasiklus, Siklus I, Siklus II, dan Siklus III

Hasil belajar afektif meliputi tiga aspek yaitu teliti dalam mengamati objek hasil percobaan, disiplin dalam mengumpulkan LKS, dan bekerja sama dalam diskusi kelompok. Aspek teliti dalam mengamati objek hasil percobaan meningkat dari Siklus I sebesar 69,44\% menjadi $72,22 \%$ pada Siklus II, dan 95,45\% pada Siklus III. Aspek disiplin dalam mengumpulkan LKS meningkat dari Siklus I sebesar 51,39\%, menjadi 79,17\% pada Siklus II, dan 93,49\% pada Siklus III. Aspek bekerja sama dalam diskusi kelompok juga meningkat dari Siklus I sebesar $64,58 \%$ menjadi $80,56 \%$ pada Siklus II dan $86,36 \%$ pada Siklus III.

Peningkatan pada hasil belajar psikomotor dan afektif dikarenakan penggunaan model guided inquiry berbantu facebook yang membiasakan siswa untuk menemukan sendiri konsep pembelajaran melalui sintak merumuskan masalah, membuat hipotesis, merancang percobaan, melakukan percobaan, menganalisis data, dan membuat kesimpulan. Hal tersebut membiasakan siswa untuk belajar dengan penemuan melaui hand on (psikomotor) dan heart on (afektif).

Penerapan guided inquiry berbantu facebook yang diimplementasikan di dalam kelas VII A SMPN 1 Kartasura memberikan peningkatan berpikir kritis dan hasil belajar siswa. Melalui model guided inquiry dengan sintaks atau tahap yang meliputi merumuskan masalah, mengajukan hipotesis, merancang percobaan, melakukan percobaan, menganalisis data, dan membuat kesimpulan dapat menuntut siswa untuk menemukan konsep sendiri melalui percobaan dengan mandiri. Hal ini sesuai dengan teori belajar penemuan dari Bruner bahwa dianjurkan siswa untuk memperoleh pengalaman dan melakukan 
ekperimen agar menemukan prinsip prinsip dalam belajar (Dahar, 2011).

Sintak guided inquiry pada tahap merumuskan masalah dan mengajukan hipotesis yang terfasilitasi dengan facebook, siswa sudah mulai berpikir tentang apa yang akan dipelajarinya melalui wacana dan gambar. Flavell dalam Dahar (2011) menyatakan bahwa anak dalam tahap operasional formal teori belajar Piaget dapat merumuskan banyak alternatif hipotesis dalam dalam menanggapi masalah dan mengecek data terhadap hipotesis untuk membuat keputusan. Hal ini sesuai dengan model guided inquiry bahwa siswa SMP yang termasuk tahap operasional formal difasilitasi untuk merumuskan hipotesis dari rumusan masalah. Siswa juga harus dapat berasimilasi untuk menggunakan struktur dan kemampuan yang sudah ada untuk menghadapi masalah dalam lingkunganya. Hal ini terkait untuk menemukan sendiri konsep pembelajaran pada guided inquiry yang dimulai dari merumuskan masalah, membuat hipotesis, merancang percobaan, melakukan percobaan, menganalisis data, dan membuat kesimpulan.

Sintak merancang percobaan dan melakukan percobaan, di sini siswa sudah bekerja mengkonstruk sendiri pengetahuannya dengan menggunakan kemampuan psikomotorik siswa. Guru memberi kesempatan siswa untuk menemukan dan menerapkan ide - ide dan strategi mereka sendiri untuk belajar yang sesuai dengan teori belajar konstruktivisme (Trianto, 2010).

Penerapan model guided inquiry dengan berbantu social network facebook ini menjadikan pembelajaran bermakna dengan pengetahuan yang didapat melalui penemuan sendiri, tidak secara hafalan. Hal ini sesuai dengan teori belajar Ausubel bahwa informasi yang dipelajari secara bermakna lebih lama diingat daripada informasi yang dipelajari secara hafalan (Dahar, 2011). Teori belajar Vigotsky juga terdapat pada guided inquiry, bahwa guru hanya bersifat membimbing dalam belajar. Guru memberikan kesempatan kepada anak untuk mengambil alih tanggung jawab yang semakin besar setelah anak dapat melakukan atau hal ini bisa disebut dengan istilah scaffolding (Trianto, 2010). Vigotsky mengungkapkan interaksi sosial saat siswa menginternalisasi pemahaman pemahaman yang sulit, masalah masalah, dan proses (Dahar, 2011). Interaksi sosial tercermin pada interaksi antar siswa dalam menemukan konsep pembelajaran.

Penggunaan guided inquiry berbantu facebook membiasakan siswa bekerja sama dan berdiskusi dengan 
teman - temannya sampai pada aspek menganalisis data dan membuat kesimpulan. Keseluruhan sintak pada model guided inquiry berbantu facebook sudah memberdayakan siswa untuk berpikir kritis dan melakukan kemampuan psikomotor dan afektif melalui kegiatan penemuan yang ada. Hal tersebut menjadikan siswa mampu menguasai konsep pencemaran lingkungan (air, udara, dan tanah) dengan baik.

Berdasarkan hasil tes kemampuan berpikir kritis dan hasil belajar siswa terjadi peningkatan yang berbeda-beda untuk tiap aspek dalam setiap Siklus. Model guided inquiry berbantu facebook mampu meningkatkan kemampuan berpikir analitis siswa. Hasil capaian tes kemampuan berpikir kritis siswa pada Prasiklus, Siklus I, Siklus II dan Siklus III telah meningkat dari target yaitu $\geq 20 \%$. Capaian tertinggi terletak pada aspek evaluation yang merupakan kemampuan untuk menilai kredibilitas pernyataan atau penyajian lain dengan menilai atau menggambarkan persepsi seseorang, pengalaman, dan situasi. Pengalaman dalam belajar dilakukan melalui sintak guided inquiry dari awal hingga akhir yang memberdayakan siswa untuk menemukan sendiri konsep belajar melalui percobaan sehingga siswa lebih mudah untuk menilai konsep belajar.
Hasil capaian hasil belajar kognitif, afektif, dan psikomotor juga meningkat, bahwa semua siswa pada Siklus III semua sudah di atas KKM (75).

Penggunaan social network facebook sebagai salah satu alternative pendukung pembelajaran juga merupakan sarana menarik siswa agar termotivasi belajar. Siswa yang sebelumnya telah membuat rumusan masalah dan hipotesis di facebook akan digunakan kembali dalam pembelajaran tatap muka di kelas. Siswa tidak hanya menggunakan facebook untuk berkomunikasi dan bermain- main namun juga sebagai sarana pendukung pembelajaran Biologi.

\section{Simpulan}

Berdasarkan hasil penelitian dapat disimpulkan bahwa penerapan guided inquiry berbantu facebook dapat meningkatkan kemampuan berpikir kritis dan hasil belajar Biologi siswa kelas VII A SMPN 1 Kartasura.

\section{Daftar Pustaka}

Amri, S. \& Ahmadi, I.K. (2010). Proses Pembelajaran Kreatif dan Inovatif dalam Kelas. Jakarta: Prestasi Pustaka Andriani, N., Husaini, I., \& Nurliyah, L. (2011). Efektifitas Penerapan Pembelajaran Inkuiri Terbimbing (Guided Inquiry) pada Mata Pelajaran Fisika Pokok Bahasan Cahaya di Kelas VIII SMP Negeri 2 Muara Padang. Prosiding Simposium 
Nasional Imovasi Pembelajaran dan Sains, 1-5

BNSP. (2006). Standar Isi Untuk Satuan Pendidikan Dasar dan Menengah. http://litbang.kemdikbud.go.id

Dahar, R. W. (2006). Teori-Teori Belajar dan Pembelajaran. Jakarta: Erlangga

Kurniali, S. (2009). Step by Step Facebook. Jakarta : PT. Alex Media Komputindo

Rustaman, N.Y. (2005). Strategi Belajar Mengajar Biologi. Bandung: UPI

Sanjaya, W. (2008). Pembelajaran dalam Implementasi Kurikulum Berbasis
Kompetensi. Jakarta: Kencana Prenada Media Group

Trianto. (2010). Mendesain Model Pembelajaran Inovatif-Progresif, Konsep, Landasan, dan Implementasinya pada Kurikulum Tingkat Satuan Pendidikan (KTSP). Surabaya: Kencana Prenada Media Group

Wenno, I. H. (2008). Strategi Belajar Mengajar Sains Berbasis Kontekstual. Yogyakarta: Into Media 